\title{
The Relationship between Work Value and Organizational Commitment on Student of Sekolah Polisi Negara Mojokerto
}

\author{
Tri Muji Ingarianti \\ Psychology Faculty, Malang University of Muhammadiyah Malang \\ Doctoral Program, Psychology Faculty, Airlangga University, Surabaya \\ Ingarianti2016@gmail.com
}

\begin{abstract}
The study has examined the work values and its relationship to organizational commitment on students of Sekolah Polisi Negara (SPN) Mojokerto. The sample included 630 students of Police Nation School by using total sampling. The instrument used were: organizational commitment scale (Ingarianti, 2015) and adaptability of work value scale (Susanti, 2014), data was analized by Correlation Rank Spearman. The result showed that work value was possitive and significant related with organizational commitment $(r=0,199 ; p=0,000<0,01)$. The effective conribution of work value to organizational commitment is about $6,4 \%$. In addition, based of six dimention of work value, it can be known the higher correlation is achievement dimention $(r=0,382 ; p=0,000<0,01)$ compared with other dimentions with effective contribution is about $15,2 \%$.
\end{abstract}

Keywords: Work value, organizational commitment, and students of Sekolah Polisi Negara.

\section{INTRODUCTION}

Human resource management is an important factor for an organization's success. Employees have important role and give big benefit to the organization for a long time, so the organization needs to pay more attention towards its members. Human as a person obviously have needs of appreciation and recognition. By fulfilling employees' needs of appreciation and recognition, they will give an achievement for the organization where they work.

Sommer, et. al (1996) stated that fulfilment of organization members' needs is really essential for members and organization. Members of organization need pleasurable job, appropriate salary, opportunity to participate in work, job promotion, and good relationship with co-workers and employer. Meanwhile, organization needs good participation, quality, and quantity from its members. The fulfilment of needs of two parties will grow the relationship between them, so high commitment from members can be emerged.

Organization which has members with high commitment will be able to surpass and compete with other organization (Meiyanto \& Santhoso, 1999). That is why organizational commitment becoming one of important variables to be examined in management, organizational behaviour, or industry and organizational psychology fields. The interest of many experts to research about organizational commitment is caused by positive and direct relation between organizational commitment with expected result, which becoming a dream of employees and employers (Mowday, Steers, \& Porter, 1982). As an example, high organizational commitment had positive correlation with high job performance, low absenteeism, and low turnover intention (Armeli, Eisenberger, \& Rhoades, 2001). Besides, the research of Meyer, Stanley, Hersecovith, \& Topolnitsky (2002) showed that employees' commitment had a correlation with intention to stay in organization and support level toward changes initiative.

Allen \& Meyer (Venugopal, Gupta, \& Singh, 2008) propose three factors influencing commitment that are personal characteristics (demographic likes gender, age, marital status, educational level and work length; dispositional consist of personality and personal value), organizational characteristics (organizational structure, policy design, and policy socialization), and organizational experiences (motivation, satisfaction, relationship between members and supervisors, and role in organization). That statement is in line with the result of Metcalfe \& Dick's study (2001), which stated that most of polices in lower position showed lower organizational commitment, while polices in officer and higher position had higher organizational commitment. It indicated that organizational experience influenced individuals' commitment.

Mowday (Dwiningrum, 2005) expressed that personal characteristic consists of age, tenure, educational level, race, gender, and personality factors including achievement motive, feelings of belonging, and job satisfaction. The previous study revealed that personal characteristics and job characteristics significantly influenced organizational commitment, even if job characteristics had bigger contribution than personal characteristics (Dwiningrum, 2005). Other study showed that age positively correlated with organizational commitment (Angel \& Perry, 1981; Osalami, 2008). The same study was conducted by Ahmad \& Ashraf (2013) and its result revealed that teachers in middle stage (31-44 years old) until the end of final career stages ( $>45$ years old) had higher 
commitment than teachers in the early career stages $(<30$ years old).

Individuals who have organizational commitment will show three attitudes that are identification of organizational goals and values, involvement and striving for the organization, and loyalty to stay as a member or part of organization (Allen \& Meyer, 1997). According to previous opinions, it can be known that organizational members will have organizational commitment if there is conformity of values between members and organization, and vice versa. In this perspective, the relationship between members and organization becomes a reciprocal or exchange relationship.

Some studies from Connor and Becker (1995) concluded that attention to members' work value in an organization was needed. If the organization can analyse and know the pattern of work value of its members, it is able to assist the smooth process of execution of duties within the organization, so members' work effectivity in organization can be realised and give big impacts to organization.

Oliver (1990) reviewed a theory about the relationship between work value and organizational commitment. The theory suggested that a state of commitment is a manifestation of what individuals possess, and any consideration of the value that leads to commitment, which is describing individuals' standard of value (Kidron, 1978).

Work value according to Hofstade (1980) is individuals' orientation and attitude toward their job, their personal relationship with organizational members, and loyalty to company or organization. It characterises individuals' hope in job. It is a person's normative predisposition in work environment and being able to be a motivation, which is called intrinsic and extrinsic values. Whether individuals like or do not like their job and work, environment will have a key role in determining their work value. Individuals therefore can be motivated both intrinsically and extrinsically in determining work value and their relationship with the place where they work.

Some researchers identified two or three similar kinds of work value (Ros, 1999) that are intrinsic or self-actualisation values, extrinsic or security or material values, and social or relational values. According to Dawis and Lofquist, data of factor analysis of Minnesota Importance Questionnaire showed that six factors of value dimension can represent 20 needs dimension. That is why these factors can be used as a reference dimension for needs description or in simply word as a value dimension. The six value dimensions are achievement, amenities, status, altruism, security, and autonomy.

The earlier study revealed that there was a correlation among work value, work attachment, and organizational commitment. Furthermore, work attachment also positively correlated with organizational commitment (Ho, Oldenburg, Day, \& Sun, 2012; Dabare \& Sajeevanie, 2014; Geldenhuys, Łaba, \&Venter, 2014). There are many literatures indicate there was a positive correlation between work value and organizational commitment (Putti, Aryee, \&
Liang, 2014; Shas, Kaur, \& Haque, 1992; Maiyanto \& Santhoso, 1999).

In this current study, organizational commitment is a dependent variable and defined as an involvement and identification of individual in an organization. Allen and Meyer (1977) proposed three concepts of organizational commitment which will be used in this study, including (1) identification of organizational goals and values, (2) involvement and giving the best for the organization, (3) loyalty to stay as a member or part of organization. Based on previous reviews, it becomes a strong reason for the researcher to do a research about the relationship between organizational commitment and work value. The purpose of the research is to find out how far the work value will affect organizational commitment.

\section{RESEARCH METHOD}

Research design in this study was non experimental - a systematic empirical study in which the researcher does not control the independent variables directly (Kerlinger, 2000). The type of this study was quantitative correlation, which used to know the correlation between work value and organizational commitment to students of National Police School/Sekolah Polisi Negara (SPN) Mojokerto.

\section{Research Subject}

The population was 750 students of National Police School/Sekolah Polisi Negara (SPN) Mojokerto, East Java. The research subject was total of population or called as a population study. This decision was made based on statement of Frankel \& Wallen (1993) who said that the amount of representative subjects in quantitative research is approximately 150 people. Darmawan (2014) also stated that research subject will be more representative if it is getting closer to the amount of population.

\section{Research Variables and Instruments}

Based on the theory and research problem, it could be known that there were two research variables: the independent variable was work value and the dependent variable was organizational commitment. Work value is beliefs, attitudes, preference, and interests in job and differences with other jobs related to construction like job satisfaction and motivation. The collecting data method for independent variable used adaptation of Susanti's work value scale (2014). This scale consisted of six dimensions which were achievement, amenities, status, altruism, security, and autonomy.

Meanwhile, organizational commitment is individual's high identification to organization, which is showed by accepting the organizational values and goals, being involved to strive for organization's interests, and being loyal to organization. The measurement of dependent variable used organizational commitment scale. This scale was made based on adaptation of Ingarianti's (2015) organizational development scale. It had 40 items 
consisting of favourable and unfavourable items based on organizational commitment's aspects, which were strong trust and acceptance of organizational goals and values of 13 items, willingness to strive for organization of 13 items, and strong desire to maintain membership in organization of 14 items, in which the level of reliability of each aspects was $0.828,0.803$, and 0.897 with total of reliability was 0.938 .

\section{RESULT}

The obtained data from the research was 630 scales. The research subject was male students aged from 17 to 22 years old. Based on analysis result, it could be known that most of research subject was 20 years old of 236 subjects (37.5\%), then followed by subjects aged 19 years old of 221 subjects (35.1\%), 18 years old of 103 subjects $(16.3 \%), 21$ years old of 67 subjects $(10.6 \%), 17$ and 22 years old of 1 subjects respectively $(0.2 \%)$. Besides getting information about subjects' age, the information about subjects' educational level could also be known. The amount of subjects who had last education in senior high school was 548 subjects (87\%), vocational school of 63 subjects (10\%), Islamic senior high school of 15 subjects $(2.4 \%)$, and unknown of 4 subjects $(0.6 \%)$.

Based on result of the study, researcher categorised work value and organizational commitment of students of SPN into two categories, which are high and low. The procedure for making a norm with two categories is called median (Winarsunu, 2007). The researcher used median score to make norm as a guideline for making a quality category of a group. Analysis result revealed that 313 students $(49.7 \%)$ had high work value and organizational commitment, while 317 students $(50.3 \%)$ had low work value and organizational commitment.

Rank Spearman's correlation test showed that there was a correlation between work value and organizational commitment of students of SPN Mojokerto $(\mathrm{r}=0.199 ; p=0.000<0.01)$ with the level of error of $1 \%$. It mean that the correlation type of these two variables was positive and significant correlation, so the higher work value of students of SPN Mojokerto, the higher organizational commitment of them. However, if their work value was low, their organization commitment would be low.

The next result indicated that every work value dimensions had a positive relationship with organizational commitment. Work value dimensions, which are achievement, amenities, status, altruism, security, and autonomy, had correlation score of 0.352 ; $0.142 ; 0.147 ; 0.133 ; 0.292 ; 0.136 ;$ and 0.199 respectively. Based on those scores, it could be known that achievement dimension had higher correlation rather than other dimensions.

\section{DISCUSSION}

The result of data analysis revealed that there was a positive and significant correlation between work value and organizational commitment of students of Sekolah Polisi Negara (SPN) Mojokerto ( $\mathrm{r}=0,199 ; p=$
$0,000<0.01)$. Thus it could be known that SPN students who had a high work value would show a high organizational commitment as well. On the contrary, the lower of work value of SPN students, the lower their organizational commitment.

Work value is beliefs, attitudes, preferences, importance of a job and its differences with other jobs related with constructions like job satisfaction and motivation. In job setting, work value serves as a basis of assessment about working conditions that affect job performance and satisfaction. It explains that work value is correlated with personality, job satisfaction, motivation, work achievement, organizational commitment, career, and work accordance with own choice (Umat, 2009).

Individuals need appreciation for their work and being recognised by their institution where they work, so they will have a meaning about the job (HemsleyBrown, 1997). According to Heuvell, Demerouti, Schreurs, Bakker, and Schaufeli (2006), it is very important to individuals to find out a meaning in doing a job. Some previous studies stated that the importance of a meaning of work in optimizing individuals function in doing a job (Heuvell, et al., 2006).

If individuals are less able to find a meaning in a job, they will leave the job easily (Heuvell, et al., 2006). Other study stated that when individuals find a meaning in a job, they will feel happy and more engaged with his job (May, Gilson, \& Harter, 2004). That is why organization should strive to strengthen employees' mental by providing jobs that can foster a sense of engagement between employees and organization (Townsend \& Gebhardt, 2008). If individuals have attachment with the organization, they will care with all of organization's needs and be able to work together, so it will improve their job performance, which gives positive impacts toward organization (Devi, 2009).

Some former researchers who conducted a study about values in general and particularly work value, suggested that work value is one of the important variables in explaining organizational commitment (Kidron, 1978; Putti et.al., 1989). Werkmeister (1967) stated that commitment is a self-manifestation and reflecting individual's value of basic standard. Some of empirical studies support this statement, which there is a relationship between work value and commitment (Kidron, 1978).

A research about interests of life, Dubin, et al. (1975) stated that employees with central life interest in doing a job will have higher organizational commitment than employees who do not have central life interest. Kidron (1978) finds a correlation between work value and organizational commitment. Putri et al. (1989) analyse relationship between work value and organizational commitment of employees in Singapura. Based on this research, it indicates that employees with intrinsic work value have stronger correlation with organizational commitment than employees with extrinsic work value.

Individuals who are committed to their organization will identify organization's goals and 
values, engage and strive for organization's interests, and have loyalty to stay in the organization (Meyer dan Allen, 1997). Members with high organizational commitment therefore are a dream for every institutions because those with high commitment show loyalty (Iqbal, Tufail, \& Lodhi, 2015), organizational citizenshipbehaviour (Allameh, Amiri, \& Asadi, 2011),high job performance and productivity in organization (Kashefi, et al., 2013; Osa \& Amos, 2014), so they will give benefit to the institution. Those reasons induce each institutions working hard to be able make its members have high commitment for instance, by giving compensation/reward and training.

\section{CONCLUSION}

Based on the result of the study, it can be concluded that research hypothesis is accepted, which means there is a positive and significant correlation between work value and organizational commitment of students of Sekolah Polisi Negara (SPN) Mojokerto $(\mathrm{r}=0.199 ; p=0.000<0.01)$. The result can be interpreted that the higher work value, the higher organizational commitment of students of Sekolah Polisi Negara (SPN) Mojokerto, and vice versa.

\section{RECOMMENDATION}

For education practitioners, this research is expected to give a description about work value and organizational commitment of students of SPN, so it can be used as a guideline while making a policy. For the next researchers, it is expected to be able to become a source of information or reference in conducting a research about organizational commitment. In addition, the next researcher is expected to find other dependent variables, such as organizational climate, job satisfaction, and many others, so in the future it will be able to give a broader description related to the concept of organizational commitment.

\section{REFERENCES}

Allameh, S. M., Amiri, S. \& Asadi, A. (2011). The survey of relationship between organizational commitments and organizational citizenship behaviour case study: Regional water organization of Mazandaran Province. Interdisciplinary Journal of Contemporary Research In Busines, 3 (5), 360 368

Armeli, S., Eisenberger, R., \& Rhoades, L. (2001) Affective Commitment to the Organization: The Contribution of Perceived Organizational Support. Journal of Applied Psychology, 86 (5), 825 - 836

Dabare \& Sajeevanie. (2014). Impact of work values on job involvement and organizational commitment of non-excekutive employees in the apparel industry in Sri Lanka. Human Resource Management Journal, $2(2), 17-27$

Darmawan, D. (2014). Metode Penelitian Kuantitatif. Bandung : Remaja Rosdakarya
Devi, V. R. (2009). Employee engagement is a two way street. Human Resource Management International Digest, $\quad 17, \quad 3 \quad-\quad 4, \quad$ doi. 10.1108/089670730910940186

Fraenkel, J. R. \& Wallen, N. E. (2009). Design and evaluate research in eduation. New York: McGraw-Hill Companies, Inc

Geldenhuys, M., Łaba, K., \&Venter, C. M. (2014). Meaningful work, work engagement and organizational commitment. SA Journal of Industrial Psychology/SA Tydskrif vir Bedryfsielkunde, 40(1), 1 - 10

Ghozali, I. (2016). Aplikasi analisis multivariete dengan program IBM SPSS 23. Semarang: Badan Penerbit Universitas Diponegoro

Hamsley-Brown. (1997). Counting nurses: Interpreting nursing workforce statistic. Health manpower management, 23 (5), 159 - 166

Heuvell, V.D., Demerouti, E., Schreurs, B.H.J., Bakker, A.B., \& Schaufeli, W.B. (2006). Does meaningmaking help during organizational change?. Career development internatonal, 14 (6), 508 - 533, doi. $10.1108 / 1362043010997277$

Ho, C., Oldenburg, B., Day, G., \& Sun, J. (2012). Work value, job involvement, and organizational commitment in Taiwanese nurses. International Journal of Psychology and Behavioral Science, 2 (3), $64-70$

Ingarianti, T. M. (2015). Pengembanagn alat ukur komitmen organisasi. Jurnal riset aktual psikologi Universitas Negeri Padang, 1, (6), 80 - 91

Kashefi, et. al. (2013). Organizational commitment and its effects on organizational performance. Interdisciplinary Journal of Contemporary Research In Busines, 4 (2), 501 - 510

Kerlinger, F. N. (2000). Asas-asas penelitian behavioral. Jogjakarta: Gadjah Mada University Press

Kidron, A (1978). Work values and organizational commitment, Academyof Management Journal, 21, 239-247.

May, D., Gilson, R., \& Harter, L. (2004). The psychological conditions of meaningfulness, safety, and avability and engagement of human spirit at work. Journal of Occupational and Organizational psychology, 77, 11 - 37, doi 10.1348/096317904322915892

Mechanic, M. A. \& Irefin, P. (2014). Effect employee commitment on organizational performance in coca cola limited Maidur, Borno state. IOSR Journal of Humanities and Social Science (IOSR-JHSS), 10, (3), $33-41$

Meiyanto, S. \& Santhoso, F. H. Nilai-nilai kerja dan komitmen organisasi: sebuah studi dalam konteks pekerja Indonesia. Jurnal Psikologi, (1), 29 - 40

Meyer, P. J. \& Allen, N. J. (1997). Commitment in the workplace theory, research, and application. Thousand Oaks, California: SAGE Publication

Mowday, R.T., Porter, L.W., \& Steers, R.M. (1982). Employee-organization linkages: The psychology of commitment, absenteeism, and turnover. New York: Academic Press. 
Mowday, R.T., Porter, L.W., \& Steers, R.M. (1982). Employee-organization linkages: The psychology of commitment, absenteeism, and turnover. New York: Academic Press.

Mowday, R.T., Steers, R.M., \& Porter, L.W. (1979). The measurement of organizational commitment, Journal ofVocational Behavior, 14, 224-247.

Oliver, N. (1990). Rewards, investment, alternatives and organizational commitment: Empirical evidence and theoretical development, Journal ofOccupational Psychology, 63, 19-31.

Osa, I. E. G. \& Amos, A. O. (2014). The impact of organizational commitment on employees productivity: a case study of Nigeria brewery, PLC. International Journal of Research in Business Management, 2 (9), 107 - 122.

Putti, J. M., Aryee, S., \& Liang, T. K. (2014). Work values and organizational commitment: A study in the Asian context. Human Relationship, 42 (3), 275 288.
Santoso, S. (2002). Mengolah Data Statistik Secara Profesional. Jakarta: Gramedia

Shas, A. A., Kaur, R., Haque, A. (1992). Work values and organizational commitment inn public and private sector industries. Pakistan Journal of sychologizal Research, 7 (3), $41-51$.

Sommers, S.M., Bae, S.H., \& Luthans, F. (1996). Organizational commitment across cultures: The impact of antecedents on Korean employees. Human Relations, 49, 977-993.

Steers, R. M. (1985). Efektivitas organizational behavior (Terj. Magdelana Jamin \& LPPM). Jakarta: Erlangga.

Townsend, P., \& Gebhardt, J. (2008). Employee engagement complety. Human Resource Management international digest, $16,22-24$, doi. $10.1108 / 09670730810869529$

Winarsunu, T. (2007). Statistik Dalam Penelitian Psikologi dan Pendidikan. Malang: UMM Press. 